\title{
Poverty Alleviation Based on Participatory Rural Appraisal in Sidoarjo Regency
}

\author{
${ }^{1}$ MASHUDI, ${ }^{2}$ LULUK FAUZIAH, ${ }^{3}$ ISNA FITRIA AGUSTINA \\ ${ }^{1}$ Department of Management, Faculty of Economics and Business, UMSIDA \\ 23 Department of Public Administration, Faculty of Social and Political Sciences, UMSIDA \\ email: ${ }^{1}$ emashud_bli@yahoo.co.id; ${ }^{2}$ lulukfauz@yahoo.co.id; ${ }^{3 i s n a a g u s t i n a @ u m s i d a . a c . i d ~}$
}

\begin{abstract}
Poverty with its entire dimension has a destructive effect due to social, economy, safety, legal, and political instabilities. This research design is a combination of qualitative descriptive and confirmatory exploration. The research variable is derived from Empowerment and Participatory Rural Appraisal (PRA) which is the designation of a competitive and sustainable empowerment management scheme. Poverty alleviation which consists of social support and protection for poor household to the empowerment of small and micro businesses has two characteristics, namely rescue and recovery. The rescue characteristic is a short-term effort to save the poor household due to the rise of fuel price, while the recovery is a long-term ones. There are problems in poverty alleviation which focuses on the empowerment and lack of engagement from local people. An increase in growth rate should increase the income per capita which will solve the problem of unemployment, poverty, and imbalance of income distribution. On the contrary, the real situation shows different fact that the increase of economic growth causes an increase of unemployment rate along with more gap in poverty and income distribution.
\end{abstract}

Keyword: poverty alleviation, empowerment, participatory rural appraisal

\section{Introduction}

A multi-dimensional poverty issue should not be viewed merely through income point of view. Poverty also includes the vulnerability and susceptibility of people both men and women to becoming poor. There is also limited access for poor people to public policy that has a great effect on their lives. Poverty alleviation has become the main topic of each development planning for it is the main issue to be solved systematically and synergistically which includes all elements of society, government, and business entities.

Poverty is not merely an individual issue; instead, it is a concern of all parties. It is because the poverty's systemic effect affects all aspects of life. Therefore, if it is not solved soon, it will worsen other issues which are in the settlement process. Poverty is closely related to data and intervention area of designation. Data has an important role to solve the poverty issues since it provides information on poor population and also becomes a benchmark of the success of a program. The dynamic characteristic of poverty has caused an up-to-date demand for poverty data.

One of the government's efforts to meet the data and information demands to solve the poverty issues is by providing Integrated Data Basis (BDT). The government of Sidoarjo Regency through BPS (Indonesian Central Bureau of Statistics) collects and processes the targeted households through the Update of Integrated Data Basis (PBDT). BPS has conducted a similar program on Social Economy Data Collection 2005 (PSE05), Social Security Data Collection Program (PPLS) 2008, and PPLS 2011. Based on the result of PBDT 2015, there were 117,270 RTS (Targeted Household) existed in Sidoarjo Regency. When the result is compared with PPLS 2011's outcome which included 99,492 RTS, Sidoarjo Regency is considered as Very Poor $(30.72 \%)$. Furthermore, the number of RTS of Poor category covered 32,353 RTS (27.59\%), Almost Poor covered 29,953 RTS (25.54\%), and Prone to Poor

Received: October 30, 2017, Revision: March 12, 2018, Accepted: June 04, 2018

Print ISSN: 0215-8175; Online ISSN: 2303-2499. DOI: http://dx.doi.org/10.29313/mimbar.v34i1.3168.112-120

Accredited B based on the decree No.040/P/2014, valid on February, 18, 2014 until February, 18, 2019. Indexed by DOAJ, Sinta, IPI 
covered 18,935 RTS (16.15\%). The different characteristic of poverty in each area requires different treatment. This situation requires the government, including Sidoarjo Regency, to be more selective in intervening poverty alleviation program in certain areas. The situation is aggravated with a limited regional budget so that the government must design the area priority to receive the policy intervention. (LP2KD Sidoarjo, 2016). The increase of poverty rate in Sidoarjo Regency also supports the above condition as can be viewed in the following figure:

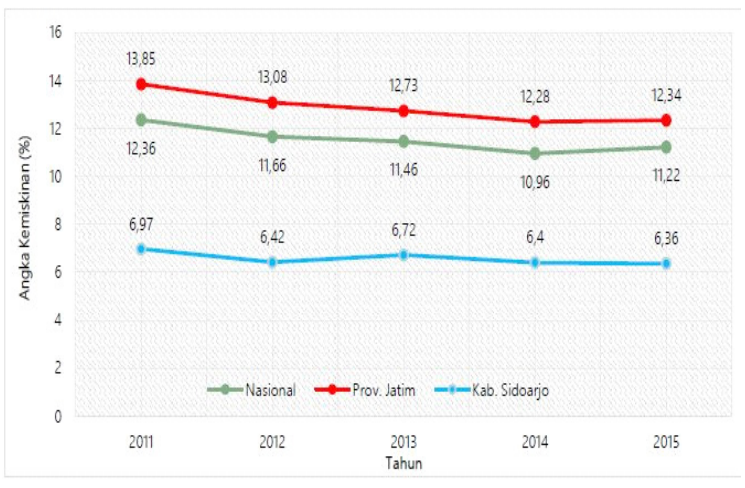

Source: BPS of Sidoarjo Regency, 2015

Figure 1:

The Increase of Poverty Rate in Sidoarjo Regency toward East Java Province and National Rate by year of 2011-2015

Based on figure 1 , the poverty rate in Sidoarjo Regency is lower than those in East Java and national's rate. The poverty rate in Sidoarjo Regency, East Java Province, and Indonesia as a whole always shows the same pattern although on a different scale. This indicates that poverty rate in Sidoarjo Regency is closely related to poverty's fluctuation both in East Java Province and national scope. One of the main challenges in poverty alleviation programs is to identify precisely the target group which will receive the benefit based on participation criteria and program goal. Basically, it refers to the pertinence of appointing the proper target of the program. Target effectiveness is believed to have a direct effect on the social security program in achieving its goal of overcoming poverty issues. In term of result optimization, local potential takes an important role. It requires potential inventory and chances of poor people mapping. This attempt is to find the suitability of area characteristics and the required model. Area characteristics includes: (1) mountainous area; (2) rural area; (3) suburban area; (4) urban area; (5) coastal area,
6) industrial area; (7) forest; (8) territorial border. Based on area characteristics, the issue of this empowerment emphasizes on one of the areas which are an industrial concentration area, especially the urban area. Based on the above issue, the problem statement in this research is how to overcome the poverty issues based on Participatory Rural Appraisal (PRA) in Sidoarjo Regency (TKPKD, 2016).

Poverty has a wide-range meaning which requires an updating on routine basis. The poverty concept requires the government to work on the personal income to be able to afford the daily needs. Kotze (in Hikmat, 2001: 6) states that poor people have good enough capacity to find income source through available opportunity. External assistance is required in certain times, but people who have received such assistance cannot rely on that because it would be very hard to predict when it will coming. This type of empowerment approach is not successful because each society cannot live alone and improved without others. This isolation produces passive attitude and in fact, resulting in poorer society members. Further, Supriatna (1997:90) states that poverty is a very limited situation without his/her own will. A poor society is signed with the low educational level, work productivity, income, health and nutrient, as well as their welfare which shows a cycle of powerlessness. Poverty may be a result of limited existence of human resource, both from formal and non-formal education which produces a low level (of informal) education.

Further, Emil Salim (in Supriatna, 1997: 82) states five characteristics of poor people, which are: (1) the inability to own his/her personal production factor; (2) the inability to achieve production asset on his/ her own; (3) the low education level; (4) the lack of facilities, and (5) there are plenty of these people who are young and do not have adequate skill or education. Booth and $\mathrm{Me}$ Cawley (In Moeljarto T., 1993) stated that in many countries there is a tendency that the increase of society welfare is measured by its income per capita, yet it can only be enjoyed by a small amount of people while the rest are even.

Poverty dimension is complex, and experts have classified it to three types (Harniati, 2007) of: (1) Natural Poverty. It is a type of poverty caused by a low quality of natural and human resources. The condition 
causes a low production opportunity; (2) Cultural Poverty. This type of poverty is closely related with one's or a group of people's attitude who do not want to improve his/her living standard even though there are other people who want to help them. This condition also occurs due to the contribution of some society tradition systems; (3) Structural Poverty. The social structure and institutional order in society are the cause of this type of poverty both directly and indirectly. The social structure here can be assumed to be organization's order and rules. Government policies often become the cause of poverty for most people.

Those three dimensions explain clearly that the poverty did not occur due to a single cause. It may be a result of natural issues which do not give any economic advantage as in natural poverty. It may also due to human factor as in cultural poverty, and in fact, it may be as well as a result of the human action through structure and institution in the society as occurred in structural poverty. Structural poverty has several characteristics to occur: First, which is very easy to indicate, is that there is no vertical social mobility at all, or else, it happens very slowly. The absence of social mobility causes the poor remain in their condition as it keeps the rich in their situation as well. The condition is a result of structural bondage which causes the absence of willingness to improve the living standard. The structural bondage has created different obstacles for the poor. Another characteristic of structural poverty is a high dependency of the poor toward other groups with a higher living standard. This fact indirectly reduces the poor ability to have a bargaining power in social relationship, in which there has already an imbalance. In this situation, social group with lower level tends to be unable to improve their life.

Poverty issue is in one of human right points which said "free from want", and clarified in the International Convention to meet the economic, social, and cultural rights of an individual. Those rights have been ratified by the nation in the form of 1945 Constitution, article $28 \mathrm{H}$ paragraph (1) which states that every individual deserves a prosperous life, living, and healthy environment as well as health service. Fighting against this type of poverty is as important as fighting for other human rights. Concern from legal expert to reduce poverty includes the renewal aspect of higher law education to produce an idealist, emancipated individual, and legal professional experts who will go for people's interest instead of pursuing the will of becoming the elites.

According to chapter $\mathrm{V}$ of Law Number 11, Year 2009 on Social Welfare, the concern above must be done by central and regional government. Even after the issuance off Law Number 23 Year 2012 on the change of Law Number 32 Year 2004 jo Law Number 12 Year 2008 on Regional Government, it is clear that the regional government has the authority and responsibility to manage its autonomy administration to reach Indonesia's goals, especially on social welfare in the form of poverty concerns. Due to these authority and responsibility, the regional government should produce more policies which aim at social welfare. The most prominent strategy in this case is to displace the individual instead of the poverty.

Achieving social welfare in perspective of Indonesian welfare state is the nation's goal which is emphasized in the Opening of Indonesia's 1945 Constitution and further explained in its articles. The effort to reduce poverty and the attempts to reach social welfare in living the freedom are not merely a matter of physical challenge, but also thought, inventions, spirit, sacrifice and hard work which has added value and gives benefits to the society. Therefore, it requires a qualified leaders and people with good health and education who are able to work hard according to their choice in living the freedom and improving the welfare of their family, society, and nation.

In the end of $20^{\text {th }}$ century, the United Nation has decided a major development agenda known as Millennium Development Goals (MDG'S) in 1990-2015 which consists of eradication of poverty and hunger; the achievement of fundamental education worldwide, as well as gender equality and women empowerment; reduction of infant and toddler mortality; health improvement for mothers; battle against HIV/AIDS, malaria, and other diseases; the clarity of environmental sustainability: and development of global partnership. The Opening of Indonesia's 1945 Constitution has included those eight agendas in its $4^{\text {th }}$ paragraph. Poverty is one of urban issues due to urbanization and urban fragmentation. This is closely related to the increase of current needs as a consequence of urbanization such as the need of works, urban facilities such as housing, economic facility and other supporting facilities (Suyatno, 
2013).

Society-centered development is a medium-term development which is popular with its approach that focuses on human empowerment. According to Hikmat (2001: 3), concept in the context of society development is always connected to the principle of independent, participation, networking and justice. People empowerment is an attempt to increase the poor's dignity. In this context, the society must involve in each development stages, started from planning, implementation and program evaluation. The society plays a role as subject of development instead of becoming passive receiver. A sustainable society's development is a bydesign and focused process which focuses on the utilization of local potential and resources as well as local people's creativeness and initiative (Mubyarto, 2002).

Based on the above formulas, it can be drawn a conclusion that society's empowerment includes the definition of community development and communitybased development, while empowering the society means the attempts to increase dignity and self-worth of the poor. Rubin in Sumaryadi (2005: 94-96) stated the 5 fundamental principles of society empowerment concept are: (1) The society empowerment requires a break-even in each of its activity which has different orientation from business organization, that is to distribute all the benefit in form of programs and other developing activities; (2) Society empowerment always involve the people in its planning and implementation; (3) In implementing the society empowerment, training is an integrated part of physical development; (4) During the implementation, the empowerment must be able to maximize the resources, especially in term of funding from government, private sector, and other sources; (5) The empowerment must function as the connector between government's macro needs and the society's micro needs.

Poverty is a situation where an individual or a family is unable to afford a decent living standard or is lacking the resources to pay the essential life needs such as food, housing, and medical treatment. It can also be defined as the lacking of minimum living standard to comfortable and secured life (Jennings 1994, Devine and Wright 1993, Burton 1992, and Chalfant 1985). Sharp (1996) in Thurlow and Wobst (2004) identified the cause of poverty from economic point of view: (1) from micro point of view, the poverty is a result of imbalanced resources ownership pattern which causes imbalance income distribution. Poor people only have limited resource with low quality; (2) Poverty is a result of different human resources quality. A low human resource quality indicates a low productivity which results in low income. The low human resource is a result of the low education level, fate, discrimination, and heredity; (3) Poverty occurs due to different access to business capital.

\section{Research Method}

This research design is qualitative descriptive mixed with confirmatory exploration. The research variables are derived from concept of Empowerment and Participatory Rural Appraisal (PRA) as the basis of scheme designation of competitive and sustainable empowerment management. In order to improve an effective and sustainable social institution, Table 1 shows several previous studies on poverty alleviation.

\section{Condition of Poverty in Sidoarjo Regency}

The cause and effect of poverty issues are complex. Policy is one the factors of poverty issues that has direct and indirect effect toward the fulfillment of poor people's fundamental rights. There has been various attempts done by Sidoarjo Regency to reduce poverty, starting from social support and security of the poor's household to the empowerment of small and micro business. The attempts are vary from the rescue program such as short-term attempt to save the poor household from the increase of fuel price, to recovery as long-term attempt to reduce poverty through the institution strengthening, the improvement of village economic facility and infrastructure, and also the improvement of human resource. Based on the development issues in Sidoarjo Regency and its main agenda in the year 2011-2015, the government designed the priority of development and general policy directions, one of which was related with poverty alleviation. One of the targets of development policy is to improve human resource through education, health, and society's income by using general policies as follow: (a) society's education level improvement; (b) society's health improvement; (c) improvement of human resource competitiveness level; (d) 
Table 1

Research Implementation of Poverty Alleviation Model

\begin{tabular}{|c|c|c|c|}
\hline No. & Research Title & Research Result & $\begin{array}{c}\text { Poverty alleviation } \\
\text { Implementation Model }\end{array}$ \\
\hline 1. & $\begin{array}{l}\text { Women Empowerment to } \\
\text { Reduce Poverty in Sleman } \\
\text { Regency. } \\
\text { By: Rosalia Indriyati } \\
\text { Saptatiningsih, dkk. } \\
\text { Year } 2015\end{array}$ & $\begin{array}{l}\text { Women empowerment } \\
\text { through skill training which is } \\
\text { adjusted with local potential } \\
\text { in motivating a productive } \\
\text { economic business. }\end{array}$ & $\begin{array}{l}\text { Poverty alleviation model } \\
\text { through empowerment } \\
\text { motivates women to improve } \\
\text { themselves in order to } \\
\text { achieve income. }\end{array}$ \\
\hline 2. & $\begin{array}{l}\text { Implementation Model } \\
\text { of Poverty Alleviation in } \\
\text { Lamongan Regency. } \\
\text { By: Achmad Syafi'i } \\
\text { Year } 2013 \text {. }\end{array}$ & $\begin{array}{l}\text { The success of the program } \\
\text { implementation of poverty } \\
\text { alleviation is affected by } \\
\text { resources, disposition, } \\
\text { bureaucracy structure, policy } \\
\text { standard and target, and } \\
\text { social politic situation. }\end{array}$ & $\begin{array}{l}\text { Program implementation } \\
\text { concerns about participation } \\
\text { and entrepreneurship values } \\
\text { improvement. }\end{array}$ \\
\hline 3. & $\begin{array}{l}\text { Society Empowerment as An } \\
\text { attempt of Poverty Alleviation. } \\
\text { By: Atma Ras } \\
\text { Year } 2013 \text {. }\end{array}$ & $\begin{array}{l}\text { The attempt is conducted } \\
\text { by new order government } \\
\text { and during reformation era } \\
\text { to reduce poverty through } \\
\text { top down and bottom up } \\
\text { approaches. }\end{array}$ & $\begin{array}{l}\text { Empowerment program model } \\
\text { involves the society starting } \\
\text { from problem identification, } \\
\text { implementation, and program } \\
\text { evaluation. }\end{array}$ \\
\hline 4. & $\begin{array}{l}\text { Poverty in Indonesia: The } \\
\text { Effect of Economic Structure } \\
\text { Growth and Change. } \\
\text { By: Sri Liani Suselo } \\
\text { Tarsidin } \\
\text { Year } 2008\end{array}$ & $\begin{array}{l}\text { Agriculture, plantation, and } \\
\text { fishery are business sectors } \\
\text { with the highest poverty } \\
\text { rate but also have poverty } \\
\text { elasticity toward the highest } \\
\text { economic growth. }\end{array}$ & $\begin{array}{l}\text { The most proper poverty } \\
\text { alleviation model is by } \\
\text { paying more attention on } \\
\text { agricultural, plantation and } \\
\text { fishery sectors. }\end{array}$ \\
\hline
\end{tabular}

an increase of society's purchasing power; and (e) the control of population growth rate.

As stated at the beginning of the chapter that the public policy has direct and indirect effect toward the fulfillment of the poor's basic rights, there is a need to conduct a review to assess the effect of public policy implementation toward respect, protection, and fulfillment of the poor's basic rights. The review also functions to understand the commitment and partnership of all parties in eradicating the poverty. Based on the understanding of poverty concept and definition, the following table can explain the poverty occurrence:

In social cultural point of view, the inability and helplessness of the poor cover four main factors, namely the mindset in the form of paradigm and motivation to survive from the poverty; the inability to make social interaction; the low motivation and lack participation of women in the family; and the lack of strengthening the role and the society. Those issues are also added with 1) the hampered of social mobility upward; 2) the low involvement in the economic activity; and 3 ) the low participation in designing public policy. The hampered social mobility upward is mostly caused by laziness, low motivation of self-improvement, and low education level of poor society compared to the oppressed of human rights. In Sidoarjo Regency, there are still many business opportunities due to its rich natural potentials. To reduce poverty, there are integrated coordination and assistance among inter-actor, cross-program in preparing formulas, and the implementation of poverty alleviation policies. As it stated before, "There are 59 poverty alleviation programs in Sidoarjo Regency with the expectation that the quality of the programs can be enjoyed by the poor, especially concerning their basic needs and services for the poor namely decent education, health, food, and housing as well as the society economic development (Sanadjihitu et al, 2015).

Another organization of TKPKD Sidoarjo has also operational budget. Within a year, Sidoarjo Regency's TKPKD requires operational budget of nearly 400.000.000 Rupiahs. It comes from the annual Sidoarjo Regency's budget. Since the establishment of Sidoarjo's TKPKD, the annual operational budget stays in the same amount. Furthermore, there are 
Table 2

Causes of Poverty in Sidoarjo Regency

Economic factor

Educational factor

Health factor

Socio-cultural factor

Area of infrastructure

Degradation of human resource and environment
The limited work field that causes many people unemployment or half-unemployed due to:

a. Limited business capital and the absence of access to get the capital because of warrant issue.

b. The high price of primary needs which is more than the ability to afford them due to his/her income.

Low education level of the family due to :

a. The mindset which believes the education is not important for life.

b. The absence/lack of non-formal education's chance.

a. Bad sanitation and environment

b. The society's mindset on the importance of health is still very low.

a. Mental and pattern of motivation (low and tend to be lazy) to reduce poverty.

b. The lack of strengthening the social role.

a. Lack of infrastructure of transportation

b. Housing

c. Lack of clean water

a. Flood, and other natural disasters.

b. The damaged field based on human resources on DNA.

c. Pollution in all kinds also Pokja (working groups) and Pokgram (group of programs) in the Sidoarjo Regency TKPDK structure. As part of an organization, it is expected to provide suggestion and reasons to reduce poverty in Sidoarjo Regency, but in fact it is not yet performed. Although the Pokja and Pokgram exist structurally, almost all program initiation and planning was done by Permanent Secretariat (Sektap) of TKPKD in Sidoarjo Regency. The support for Sidoarjo Regency's government policy in reducing poverty is shown in Table 2.

TKPKD of Sidoarjo Regency coordinates with various stakeholders in attempts of poverty alleviation in Sidoarjo Regency. It can be in the form of Regional Work Unit (SKPD) substance advocacy in documents and regional planning (RPJMD until Renja SKPD). TKPKD of Sidoarjo Regency always has an intense coordination with SKPD as well as related stakeholder. This is as an attempt to inseminate that the poverty alleviation is a mutual issue which requires a comprehensive solution. By reviewing policy intervention priority analysis in Sidoarjo Regency, it can be drawn a conclusion as follow: First, to maintain and even suppress the poverty rate in Sidoarjo Regency, it requires optimization of basic needs fulfillment which can be reached by the poor people. The inability of poor people to fulfill their basic needs is in general related to the failure of assets ownership of land and capital, the limited basic service of health and education, the limited basic of facility and infrastructure, and the weak participation of the society in public decision taking which causes the low productivity and society capital establishment in fulfilling a decent living need. Second, the availability of data related to main and supporting indicators to sub-district level that is greatly needed as a measurement tool in controlling the policies and current program achievement and in the future. And third, the use of integrated data basis is inevitable in appointing poverty alleviation program and target (location and addresses of the recipient). Therefore, updating and periodically synchronizing the data is needed to serve up-to-date data for establishing partnerships in conducting poverty alleviation programs.

Based on policy support that becomes the basis and framework of poverty alleviation efforts as a follow up of national strategy, it requires main strategies of (1) reducing the expense of poor people; (2) improving the skill and income of the poor; (3) improving and ensuring the sustainability of small and micro business; and (4) strengthening the institutions of poverty alleviation in order to make synergy of poverty alleviation policy and program. 
Table 3

Policy Support of Sidoarjo Government

\begin{tabular}{|c|c|c|}
\hline No & Program Title & Poverty Alleviation Activity \\
\hline 1 & $\begin{array}{l}\text { Rehabilitation Program of } \\
\text { Uninhabitable Home (RRTLH) }\end{array}$ & $\begin{array}{l}\text { To make new criteria of uninhabitable home as } \\
\text { the result of coordination between executive and } \\
\text { legislative. }\end{array}$ \\
\hline 2 & $\begin{array}{l}\text { Multi Grade Teaching Program } \\
\text { (Education) }\end{array}$ & $\begin{array}{l}\text { Support for students from poor families in rural and } \\
\text { remote area (Jabon and Buduran sub-districts) in the } \\
\text { form of boat machine. }\end{array}$ \\
\hline 3 & $\begin{array}{l}\text { CSR Program/ activity and facility of } \\
\text { Sidoarjo Regency }\end{array}$ & $\begin{array}{l}\text { CSR is a social awareness program and activity from } \\
\text { the company for the society and its surrounding. This } \\
\text { program implementation has started from the year } \\
2000 \text {. }\end{array}$ \\
\hline 4 & $\begin{array}{l}\text { Work Opportunity Enhancement } \\
\text { Program }\end{array}$ & $\begin{array}{l}\text { Empowerment of unemployment through labor- } \\
\text { intensive activity (tertiary water channel normalization } \\
\text { and terracing). }\end{array}$ \\
\hline 5 & $\begin{array}{l}\text { Family Empowerment Post } \\
\text { (Posdaya) }\end{array}$ & $\begin{array}{l}\text { POSDAYA functions as one of the advocacy site to } \\
\text { accommodate the society's aspiration accordingly. }\end{array}$ \\
\hline 6 & $\begin{array}{l}\text { The society nutrient and health } \\
\text { service improvement }\end{array}$ & $\begin{array}{l}\text { This program is conducted to support and empower } \\
\text { the society to be independent in managing their } \\
\text { family's nutrient (in the form of Posyandu, Poskesdes, } \\
\text { and Polindes) and it has started since the year } 2007 \\
\text { up to present. }\end{array}$ \\
\hline 7 & One Day Service Program & $\begin{array}{l}\text { This program is to smoothen business permit for } \\
\text { Middle Level Enterprises which specifically employing } \\
\text { the poor people (unemployed) and it started from the } \\
\text { year } 2006 \text { up to present. }\end{array}$ \\
\hline 8 & $\begin{array}{l}\text { Social Welfare Rehabilitation and } \\
\text { Service Program }\end{array}$ & $\begin{array}{l}\text { This program started in } 2009 \text { up to present and is } \\
\text { dedicated for poor and abandoned elderly. }\end{array}$ \\
\hline
\end{tabular}

\section{The obstacles of Poverty Alleviation in Sidoarjo Regency}

The obstacle exists in alleviating the poverty rate in Sidoarjo Regency is the action/implementation as an important policy agenda because the government takes the responsibility according to the 1945 Constitution which explicitly requires the government to protect its citizen's rights. Therefore, when government ignores this issue, it will violate the constitution. Besides, the poverty alleviation becomes an obligation for the government since it becomes a global commitment of the United Nations (United Nations, 2011) in 2011 Summit which generated MDGs declaration to achieve community welfare in the year 2015.

According to Fauziah et. al., (2017) in previous research related to poverty experienced by women as home-based worker with putting out system, she explained that home workers experienced exploitation because the work was done at home and they spent a great amount of time to finish it yet they received a very low income, had no bargaining power, and there was no certainty of work continuity. There are striking characteristics of home-based worker: nonconducive workplace, low income, and no social and law protection. That is the starting point of home worker poverty which dropped their economic level.

Other obstacles to be faced are the instability of government system, excessive environmental usage, and women and elderly discrimination and helplessness. The imbalance rice distribution among the poor, the increase of foods prices, the decrease of 
real income and the high rate of unemployment are the main factors of poverty. According to the researcher, the poverty alleviation based on participatory rural appraisal (PRA) must be understood comprehensively. The current analysis shows that there is lack of understanding on poor people characteristics, no real issues reference faced by the poor, non-individual basis, and an unsustainable process of policy implementation.

Approach solution of poverty alleviation should refer to several indicators namely : 1 ) the individual success must be complemented with the group and society achievement; 2) conventional poverty must be corrected in dealing with local condition which has specific local nature; 3) Poverty alleviation paradigm by recognizing the participation and empowerment potential of the poor as the main actor in fighting against poverty; 4) The performance of poverty alleviation is not determined by the accurate indicator/criteria, but rather by the concern and commitment of program agents; 5) the unsustainability of the program which is considered good and successful caused the ineffective and inefficient poverty alleviation program, and 6) The poverty alleviation would be determined by society participation with the basis of and considered the social capital of the poor to improve themselves.

Specifically, the poverty alleviation based on participatory rural appraisal (PRA) as a benchmark for the future should be based on reorientation focus and approach namely: a) the focus of poor family empowerment is on food, education, and health services; b) the policy focused on the structural transformation of agricultural to non-agricultural sector; c) to build the independent poverty alleviation through the empowerment of poor community; d) to make role reposition of external sides from the development agent in becoming the empowerment facilitator.

In the society with paternal culture like Sidoarjo, most people feel in weak position which resulted in the existing of more poor people. They are women where in the patrilineal society are considered as male subordinates, marginalized, and discriminated. This strengthens the existence of. Housewives whose age 19 and above, reviewed in Sidoarjo population by the year 2016 , became the most population of feminism poverty. Besides, women culturally receive domestic role and responsibility. This means they handle all the family's consumption and needs on daily basis. When the family lacks of financial support, the women will suffer more.

\section{Conclusion}

Poverty issues require intervention from all sides at once and centralized. The poverty alleviation currently tends to be partial and unsustainable. The role of business world and the society in general is not yet at its greatest rate. The social volunteers in the society can become an important source of empowerment while the poverty alleviation solution is started to slowing down. Therefore, it requires a more systematic and thorough change for the poverty alleviation programs. The society empowerment to alleviate poverty will not work without active participation from all society members.

Poverty alleviation is conducted in multi-sectors with all sides/institutional support. The society empowerment in alleviating poverty must become an important agenda because the government carries responsibility in accordance to the 1945 Constitution (The 1945 Constitution of the Republic of Indonesia) which explicitly gives a mandate to the government to protect its citizens' rights. Therefore, if the government ignores this issue it means that the government has violated the constitution. The ineffective poverty alleviation program is due to the limitation in viewing its aspect merely through economy and the emphasizing of empowerment and the lack of local people's participation. Therefore, along with a high growth of economy there will be a rise in the income per capita which will solve all issues of unemployment, poverty, and imbalanced of income distribution. Nevertheless, the fact showed different result that the economic growth caused more unemployment rate, imbalanced poverty, and income distribution which became more severe.

\section{References}

Atma Ras, (2013), Pemberdayaan Masyarakat Sebagai Upaya Pengentasan Kemiskinan. SOCIUS. Volume XIV, Oktober - Desember.

Badan Pusat Statistik (BPS), (2015), Kabupaten Sidoarjo. Sidoarjo Dalam Angka.

Harniati,(2007), Tipologi Kemiskinan dan Kerentanan Berbasis Agroekosistem dan Implikasinya Pada Kebijakan Pengurangan Kemiskinan. Disertasi tidak diterbitkan. 
Bogor: Sekolah Pascasarjana Institut Pertanian Bogor.

Hikmat, H., (2001), Strategi Pemberdayaan Masyarakat. Bandung: Humaniora.

Laporan Pelaksanaan Penanggulangan Kemiskinan Daerah Kabupaten Sidoarjo (LP2KD), (2016).

Law Number 11 Year 2009 on Social Welfare

Law Number 23 Year 2012 on the Change of Law Number 32 Year 2004

Law Number 12 Year 2008 on Regional Government

Fauziah L., Mashudi, Mariyati L. I., \& Choiriyah U. I, (2017), Wage System of Female Worker Based on Putting Out System in Sidoarjo Regency. MIMBAR, Vol. 33. No.1, 149-157.

Mubyarto, (2002), Kajian Strategis Indikator Kemiskinan. Penerbit Balitbang Provinsi Jawa Tengah.

Moeljarto, (1993), Politik Pembanguan Sebuah Analisis Konsep, Arah dan Strategi, PT. Tiara Wacana: Yogyakarta.

Sanadjihitu, S., Totok, A. W., \& Fauziah, L., (2015), Karakteristik Kemiskinan dan Penanggulangannya di Kabupaten Sidoarjo. MIMBAR, Vol. 31, No. 2 (Desember, 2015): 495-506

Saptatiningsih Rosalia Indriyati, Nugrahani Tri Siwi dan Rejeki Sri, (2015), Pemberdayaan Perempuan Desa Untuk Mengurangi Kemiskinan. Jurnal ISBN 978-602-736903-0. Volume XIV, Oktober.

Sumaryadi, (2005), Perencanaan Pembangunan Daerah Otonom dan Pemberdayaan Masyarakat. Jakarta: CV Citra Utama.
Suparjan, H. S., (2003), Pengembangan Masyarakat dari Pembangunan sampai Pemberdayaan. Yogyakarta: Aditya Media.

Supriatna, T., (1997), Birokrasi Pemberdayaan dan Pengentasan Kemiskinan. Bandung: Humaniora Utama.

Suselo S. L. \& Tarsidin, (2008), Kemiskinan Di Indonesia: pengaruh Pertumbuhan dan Perubahan Struktur Ekonomi. JEL Classification: 010, 049.

Suyatno, B., (2013), Anatomi Kemiskinan dan Strategi Penanganannya. Malang: InTrans.

Syafi'I Achmad, (2015), Model Implementasi Program Pengentasan Kemiskinan Di Kabupaten Lamongan (Implementation Model of Poverty Awakeness Program in Lamongan Region). DIA, Jurnal Administrasi Publik Desember 2013, Vol. 11, No. 2, Hal. 197 - 214.

The 1945 Constitution of the Republic of Indonesia.

Thurlow, J. \& Wobst, P., (2004), "The Road to Pro-Poor Growth in Zambia: Past Lessons and Future Challenges." Forthcoming Development Strategies and Governance Division Discussion Paper, International Food Policy Research Institute, Washington, D.C. Input paper into the World Bank project "Operationalizing ProPoor Growth," Washington, D.C.

Tim Kordinasi Penanggulangan Kemiskinan Daerah (TKPKD) Kabupaten Sidoarjo Tahun (2016).

United Nations, (2011), Objective and Themes of the United Nations Conference on Sustainable Development: Report of the Secretary-General. UNCSD, New York. 